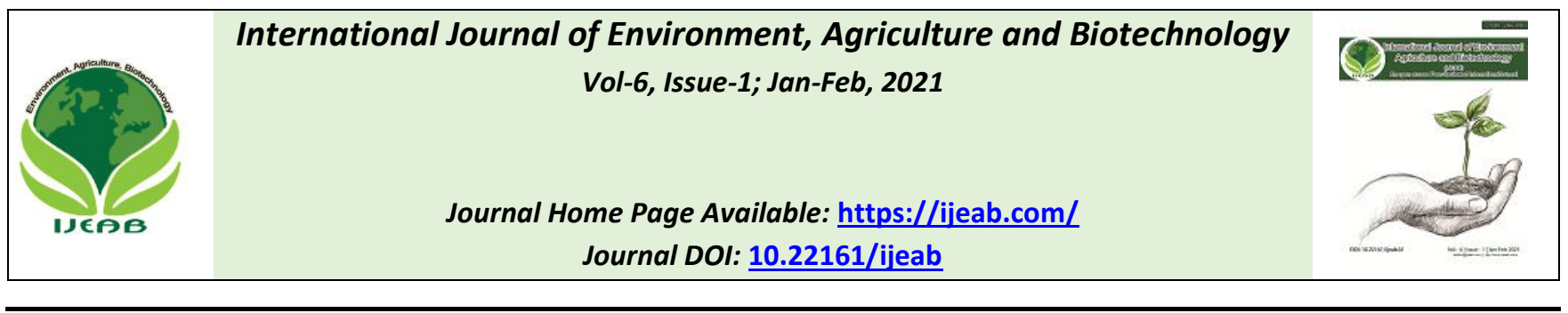

\title{
Impacts of Dams on the Environment: A Review
}

\author{
Yousra Mohamed Khir Alla ${ }^{1}$, Lee Liu ${ }^{1,2^{*}}$
}

\author{
${ }^{1}$ Department of Environmental Engineering, Northeast Normal University, Changchun, Jilin, China \\ ${ }^{2}$ School of Geoscience, Physics, and Safety, University of Central Missouri Warrensburg, MO 64093. USA \\ *Corresponding Author
}

Received: 01 Nov 2020; Received in revised form: 10 Jan 2021; Accepted: 20 Jan 2021; Available online: 28 Jan 2021

(C2021 The Author(s). Published by Infogain Publication. This is an open access article under the CC BY license

(https://creativecommons.org/licenses/by/4.0/).

\begin{abstract}
Dams are very important for generating electricity and providing drinking water. However, they have major negative impacts on water quality, aquatic ecology, land, terrestrial wildlife, vegetation, and air quality. Mitigation measures should be put in place to reduce these negative impacts on the environment. For example, to reduce the impact on water quality, sediment control drainage should be constructed. To control chemical pollution, containers should be provided for chemical waste. With respect to climate and GHG emissions, it is critical to clear vegetation prior to reservoir filling. Overall, dams negatively affect the physical and biological environment due to the various activities, during construction, filling the reservoir and during the operation of the reservoir and dams.
\end{abstract}

Keywords-Dams, environment, impacts on climate, reservoir, water quality.

\section{INTRODUCTION}

Population growth and development in technology and constructions such as building large cities and building roads, bridges and dams have led to an imbalance in the ecosystem and a loss of the ecological balance (Huesemann and Huesemann, 2011). Day after day, the interest in the environment increases, and as the interest in it increases, contradictions abound between environmental officials and engineers who know that the construction of engineering projects, especially dams, causes a lot of damage (Gadgil and Guha, 1994). From other aspects, we know that the construction of engineering buildings or industrial projects contributes to the development and development of the country from all aspects, economically and socially (Tibaijuka, 2009). When planning the construction of any project, you should pay attention to the environmental problems and how this project will affect the community and the organisms, it is not necessary to pay attention only to the economic value (Richter et al., 2010). Among the development projects, large dams are of great interest to the agencies and the World Bank (Ledec and Quintero, 2003). Environmentalists talked about the environmental and social impacts resulting from the construction of dam projects, such as population migration and the change in biodiversity, while the owners of hydroelectric projects talked that dams are a source of renewable energy (Basson, 2004). Dams produce many negative impacts on the environment and society, including during construction, and these end after the completion of construction, but the most serious impacts are in the operational phase, which lasts for thousands of years. It may also result from civil works, such as building roads, drilling, power transmission lines, and others. This paper summarizes the adverse of environmental impacts associated with dams during the reservoir impoundment, construction and operation, along with the typical kinds of mitigation measures.

\section{ENVIRONMENTAL IMPACTS FOR DAMS}

There are many potential impacts of dams on the physical and biological environment at the construction site, reservoir area and downs stream areas. These impacts were summarized in (Tables 1 and 2). We will discuss them in details as flow:

\subsection{Impacts on Water Quality}

Dams are being constructed due to the increasing demand for water and energy, however there are negative environmental impacts resulting from dams. 


\subsubsection{During Construction}

The construction sites may be the origin of water pollution resulting from activities inappropriately managed and monitored, which may affect water quality downstream. Impacts typically observed in such circumstances concern the release of excessive sediment loads in the river stream, the release of chemicals (Skaggs et al., 1994). Moreover, the distribution and cycling of chemical compounds in water bodies, such as dams, are closely related to water movement in the landscape and are influenced by processes in the hydrological and biological cycles (Lewis, 2002).

\subsubsection{Excessive Sediment Release}

Release of high sediment load in water may occur mainly during works in or close to river bed: diversion channel construction, excavation works at dam site, construction of protection dikes and coffer-dams, quarrying works, sand borrowing in river bed, creation of spoil areas too close to the river bank or with unstable slopes, etc. All these activities may have significant impacts on the sediment load discharged into the river (Wahlstrom, 2012). Most of these works will occur during the dry season, when the river flow is low. During the works, water infiltrated from the alluvial aquifer into the excavation will need to be pumped. Pumped water with heavy sediment load is frequently just discharge into the nearby stream generally consisting of low flow of very clean water drained from the superficial aquifers (JeanBaptiste et al., 2007).

The high sediment loads may reach the river at the beginning of the rainy season, when the first heavy storms wash out unstable slopes of spoils or bare soils in the construction sites or camps, or along the access roads. However, the impact at this period of the year is less detrimental because of the much higher flows in the river which carry already a high sediment content (Visser et al., 2002 and Murakami, 1995).

\subsubsection{Pollution from Hazardous Substances}

During the construction of dams, a large amount of gasoline, lubricant products, and a large amount of explosives and chemicals (concrete topping, solvents, paints, thinners, acids) will be stored and processed at the construction site, and there is a risk of leakage or accidental leakage surroundings. This risk can be efficiently reduced by the implementation of preventive management procedures by the contractor: appropriate location of storage areas with a design complying with international good practices (bonded storage), collection and recycling of used oils, monitoring of all hazardous products with specific handling procedures and contingency plans (Webb et al., 1995 and Basnyat et al., 2000). Another source of pollution is represented by the batching plants, and particularly by the effluent from concrete truck cleaning which consist of wastewater with ISSN: 2456-1878 high $\mathrm{pH}$ and contaminants from the concrete additives. In case of direct release into the river, there may be severe effects on the downstream population which relies on the river for domestic and cattle water supply, washing and irrigation (Ellison, 2007).

\subsubsection{Pollution from Domestic Wastewater}

The operator's region and other temporary worker camps will probably accommodate few thousands of workers. Without appropriate sanitation system and wastewater treatment, the release of pathogens and Coliforms in the river may severely affect the population downstream (Jafarinejad, 2016).

\subsubsection{Pollution from Solid Waste}

During the construction of the dam, a very large amount of solid waste will be generated either from municipal or construction principle. Most of these waste, if not appropriately managed, may result in soil and water pollution, with possible detrimental impacts on the environment and on public health. Domestic waste will be produced by the worker camps (Chandrappa and Das, 2012; Tatsi and Zouboulis, 2002).

\subsubsection{Impacts during Reservoir Impoundment}

\subsubsection{General Consideration}

As the terrestrial area becomes flooded with rising water immediately following dam closure, several processes occur which have a dramatic effect on the impounded water quality. An eutrophication process will be initiated, where plants, starved of atmospheric oxygen die and start to decompose which, when combined with the decomposition of the organic matter from the top soil, depletes the dissolved oxygen of the reservoir water. If this deoxygenated water is not replaced quickly enough, then anoxic conditions will develop at the bottom of the reservoir (Spoor, 1990).

Hypoxia causes a reducing environment that changes insoluble compounds into soluble ones with the help of anaerobic bacteria with considerable unfavorable consequences: liberation of ammonia, metals such as iron, manganese, sometimes mercury. Additionally, Sulphate will be reduced to the highly acidic hydrogen supplied by bacteria which can corrode metal components of the turbines (Naja and Volesky, 2009). The riskiness of these changes is very harmful to both the aquatic life and the electro-mechanical equipment. The extent and severity of the anoxic region depends upon several parameters, the major being the quantity of organic matter flooded and the characteristics of the reservoir. Another consequence of the vegetation flooding is the release of nutrients such as nitrogen and phosphorus, which participate in the eutrophication process of the reservoir, with dramatic 
consequences on water quality in the long term (Goldman, 1976 and Ashton et al., 2001).

\subsubsection{Flooded Biomass}

The most active part of the biomass regarding the decay process and the consumption of dissolved oxygen is the soft biomass: fresh grasses, tree leaves, fruits and twigs. Hard biomass, represented by wood, decays very slowly in water, and if permanently flooded can stay for decades. Organic matter located in the first few centimeters of top soil contributes also quickly with the soft biomass to the fast decay process. The denser the vegetation cover flooded, the higher the degradation of the water during the first few years after impoundment (Zimmer, 2008).

\subsubsection{Biomass Reduction}

Some pre-impoundment measures can be taken in order to reduce as much as feasible the risk of water alteration. The most evident measure is the removal of the fresh vegetation by clearing. Two measures can be considered:

-Grassland, scrubland and fallow land located within the reservoir: burning of the vegetation during the last two or three months before impoundment, to avoid any significant regrowth of vegetation.

-Forested areas: these are small and localized areas mainly located in the upstream part of the reservoirs. Physical clearing with collection of wood by the local population and burning of the wood waste not collected.

Burning is advisable both in terms of water quality preservation and global warming prevention. Indeed, burning consumes atmospheric oxygen and releases carbon dioxide while decay consumes dissolved oxygen in water and, when oxygen is no more available in water (this happens very quickly), it turns to anaerobic process with the release of methane gas. This situation is more detrimental in terms of global warming, because methane is 25 times more damaging than carbon dioxide (Miranda, 2001 and Coutant, 1999).

\subsubsection{Floating Debris}

If there vegetation cover, it is anticipated significant volumes of floating debris during the impoundment stage. Some facilities will be required at the spillway to collect and haul any major debris (tree) brought by the flood (Erikson, 1976).

\subsubsection{Impacts on the Downstream Zone}

As soon as the filling starts, some load of organic matter will be transported by the water and released downstream. The water will probably have a reduced dissolved oxygen content if not temporarily anoxic, and some fish kills could be observed downstream of the dam (Miller and Miller, 2007).
With an increased organic load in the downstream, the water may taste badly and could possibly be during few months incompatible with its use for domestic and animal drinking purposes. Typical mitigation measure is to provide the concerned villages with a water supply independent from the river water, generally hand pumps connected to the superficial alluvial aquifer (Baxter, 1977).

\subsubsection{Impacts during Reservoir Operation}

Forecasting of the most probable condition in the reservoir after impoundment and during the operation years is a perilous exercise. However, observation of phenomena in existing reservoirs all over the world and particularly in Africa has set up the basis for empirical modelling to assess mainly the nutrient and potential productivity in the future water body. Special criteria have thus been established to allow comparison and prevision, related mainly to the morphometry (shape) of the reservoir and to the water management (Gruner, 1963).

Predictions on the possible future characteristics of the Dams reservoirs are provided in the following:

\subsubsection{Residence Time}

The hydraulic residence time is related to the duration water is expected to stay in the reservoir. It is the ratio between the reservoir volume and the annual inflow. Indeed, the longer the water stay, the higher is the nutrient concentration and the risk of reservoir eutrophication. The faster the water is renewed in the reservoir, the lower is the risk of its quality degradation when compared with the inflow quality (Kunz et al., 2011).

\subsubsection{Shoreline Development}

The reservoir shoreline development expresses the ratio between the reservoir perimeter and the circumference of a circle of an equivalent area. When a reservoir is highly dendritic, there is a risk of insufficient circulation and renewal of water in some isolated parts with local risk of eutrophication and aquatic vegetation development (Wetzel, 2001).

\subsubsection{Temperatures and Reservoir Stratification}

Temperatures prediction for reservoirs depend on geographical and meteorological criteria. The limited mean depth of the reservoirs means that a significant area of the reservoirs will consists of shallow waters which generally show higher temperatures (Loucks, 2017).

\subsubsection{Electrical Conductivity and Salinity}

Electrical conductivity or salinity should increase with time in the reservoirs, as a result of salt built-up resulting from evaporation. Could eventually pose a threat for irrigation (Mollema, 2016). 


\subsubsection{Nutrient Loading and primary Productivity}

Since phosphor is generally the nutrient limiting factor for primary production, it is considered as the key criteria for anticipating on the eutrophication risk of a reservoir. Phosphor (P) is an important macronutrient. The productivity of aquatic systems decreases due to the scarcity or lack of bioavailability of the primary producers. Conversely, the addition of dissolved $\mathrm{P}$ to aquatic ecosystems often stimulates eutrophication, leading to blooms of algae, Phytoplankton or floating macrophysics on water surfaces (Carpenter et al., 1998).

\subsubsection{Reservoir Sedimentation}

Rivers carry four different types of sediments downstream that allow formation of river banks such as deltas, silt, river drift phenomena, crescent-shaped lakes, dikes and coastal beaches. The construction of dams prevents the flow of these sediments to the downstream, which leads to the erosion of the riverbed from this sedimentary environment and the accumulated sediments in reservoirs or dams increase (McCully, 1996). The rate of precipitation varies between each dam and river and reservoirs put an end to water storage due to the exchange of storage space for sediments. Declining storage capacity results in a decrease in the capacity to produce hydropower, such as reduced availability of water for irrigation, and if left untreated, it may eventually lead to a failure in the dam and also in the river (Stevens, 2000).

\subsubsection{Mitigation}

\subsubsection{Sediment Control}

Drainage of construction sites and the use of sedimentation ponds in critical location inside or close to the river bed will be required from the concerned Contractors.

\subsubsection{Pollution from Chemicals}

Provide containers for all chemicals and chemical waste including fuel, engine oil and hydraulic fluids. Monitoring and recording of the quantities of used oils and used hydraulic fluids will also be required. These waste will constitute most of the hazardous waste produced on site. Contractors should have an option for recycling such as producing low grade diesel or using as an alternative fuel.

Obligate for contractors will also to prepare and implement a spill response plan including management of storage sites and equipment related to spill control (Kumari and Singh, 2018).

\subsubsection{Pollution from Worker Camps}

Worker camps must be equipped with a sanitation system in order to collect and treat all grey and black waters produced by the camps before discharge into the environment. Construction sites will be equipped with a sufficient number of toilets in order to control pollution discharge into the river streams.

Regular controls of faecal Coliforms must be carried out during construction in order to ensure treatment efficiency of the wastewater before discharge (Adams et al., 2008).

\subsubsection{Pollution from Solid Waste}

The main contracting companies must develop action plan regarding solid waste management. This plan should cover (1) the management of domestic waste from the camps, (2) the management of non-dangerous construction waste and (3) the management of hazardous solid waste (Robles, 2010).

The necessary measures to treat polluted water (such as sewage treatment plants or enforcement of industrial regulations) may be needed to improve reservoir water quality. The selective forests within the reservoir area must be removed and disposed of before filling in order to avoid the decay of the submerged biomass that causes a decrease in the water quality.

\subsection{Impacts on Aquatic Ecology}

The closing of the rivers by the dams deeply modify the local aquatic ecology, which shift from river to lake habitat. The permanent floods inundate the surrounding wetlands, forests and other habitats in the river, and this leads to further disruption of the ecosystem that occurs along the banks of the river and the estuary, as the areas surrounding the banks of the river are characterized by being the richest in biodiversity (Ward et al., 1998).

Dams suppress sediments that would naturally regenerate downstream ecosystems and because of this, some endemic species may or may not survive environmental changes. New species are likely to be dependent on adaptive habitats. However, dams have altered and made the main ecosystem. It adapts to this change, and it is clear from the construction of dams and reservoirs that they reduce the diversity of wildlife, either for better or for worse, and also leads to the loss of habitats for many organisms (Power et al., 1996).

\subsubsection{Impacts on Fish Biodiversity}

The construction of dams negatively affects the aquatic organisms, especially fish, and when the dam is closed, the migratory fish are automatically destroyed due to inconvenience to spawning and they cannot reproduce, and this is a major reason for these fish switching from river water to lake water, and this makes sensitive fish vulnerable. Therefore, the number and types of fishes will change, which impact remarkable local fisheries. Aquatic living of EIPA mainly contained: (1) assessing the effects of the construction project on the planktonic animals and plants, benthic organisms, higher aquatic plants, fishes and other aquatic animals etc.; (2) focusing on evaluating the impact 
on rare aquatic livings; (3) analyzing the effects on the habitats of fish spawning; (4) discussing the efficiency of conservation measures for aquatic livings and proposing further protection measures. Fish and other aquatic species cannot survive in artificial lakes; changes in downriver flow patterns adversely affect many species, and water quality deterioration in or below reservoirs (usually low oxygen levels; sometimes gas super-saturation) kill's fish and damages aquatic habitats. Freshwater mollusks, crustaceans, and other benthic organisms are even more sensitive to these changes than most fish species, due to their limited mobility (Bai et al., 2011).

\subsubsection{Mitigation}

Management of water releases may be needed for the survival of certain fish species, in and below the reservoir. Fish hatcheries can be useful for maintaining populations of native species which can survive but not successfully reproduce within the reservoir. They are also often used for stocking the reservoir with economically desired species, although introducing non-native fish is often devastating to native species and not ecologically desirable. Fishing regulation is often essential to maintain viable populations of commercially valuable species, especially in the waters immediately below a dam where migratory fish species concentrate in high numbers and are unnaturally easy to catch.

\subsection{Impacts on Land Use}

\subsubsection{Permanent Land Occupation}

In the dam construction zone the permanent land occupation features comprise the dam and dyke structures and the power plant and switch yard. The land use at the different locations of the permanent land occupation (Beilfuss et al., 2000).

Reservoirs may contribute to changes in Earth's climate. Hot climate reservoirs generate methane, which is one of the greenhouse gases at stratigraphic reservoirs, which are below the oxygen layers (meaning they lack oxygen), and this leads to the degradation of biomass through anaerobic processes. In some cases when water floods large basins and the size of the mass the vitality is high, it converts it into methane, so the potential pollution results are 3.5 times more than that of an oil-fired power plant (Roht-Arriaza, 2009).

\subsubsection{Access Roads}

When building dams, new roads are usually created to reach the dam, and this leads to changes in land use, especially if forests are removed to create these roads in this case, this will also lead to a new problem, which is the loss of biodiversity and the acceleration of erosion. Some projects do not need to construct new access roads to the reservoir and this goes beyond the environmental impacts (Patz et al., 2000).

\subsubsection{Mitigation}

Obtainment the maximum use of the existing roads and paths to reach the dam site. Thus avoiding the need to create a specific access road that reduces the impact on land use.

\subsection{Impact on Vegetation}

\subsubsection{Impacts during Construction}

Dam construction, weed invasion, agricultural practices, and overgrazing are the main pressures that threaten riparian vegetation, and then influence the river Geomorphology and river ecosystem (Kondolf et al., 2007). These activities affect the dynamic processes and environments of river, and lead to changes in vegetation succession in the riparian zone. Among these, river damming is essential to anticipate a barrier's long-term environmental influence and a dominant anthropological effect on river systems (la Cecilia et al., 2016). As riparian vegetation is closely connected to discharge stochasticity, it can experience remarkable changes after the construction of artificial reservoirs (Tealdi et al., 2011).

\subsubsection{Impacts during Reservoir Impoundment}

\subsubsection{Floating and Aquatic Vegetation}

Floating aquatic vegetation and aquatic weeds can rapidly proliferate in eutrophic reservoirs, causing problems such as (a) degraded habitat for most species of fish and other aquatic life, (b) improved breeding grounds for mosquitoes and other nuisance species and disease vectors, (c) impeded navigation and swimming, (d) clogging of electromechanical equipment at dams, and (e) increased water loss from some reservoirs (Ledec and Quintero, 2003).

\subsubsection{Impacts during Operation Period}

During the operation of the dam reservoir, seasonal fluctuations in the water level occur. At the end of the dry season, the water level will be at a specified height above sea level. With the first rains, the flood gates will be closed at a predetermined date to fill the reservoir to its maximum operational level during the rainy months. The rest of the year, the water level is gradually dropping. The area exposed between the maximum and minimum operating levels is known as the landing zone, and plants can develop in this zone. These plants grow naturally and consist of herbs that are prevalent in the area. Alternatively, these areas can be used for cultivation (Furey et al., 2004).

\subsubsection{Mitigation}

- The avoidance and minimization of impacts on land use. 
- With respect to the impact on vegetation from reservoir impoundment, the impact is unavoidable. Regarding the risk of aquatic weeds, a monitoring of aquatic vegetation in association with post impoundment monitoring of water quality is recommended and an action plan for the management of aquatic weeds should be established.

\subsection{Impacts on Terrestrial Wildlife}

\subsubsection{Impacts during Construction Activities}

\subsubsection{Dust and Noise}

Along paths, roads, and transmission lines, the source of noise and dust are mainly vehicles that transport materials, people, and equipment. Construction site noise and dust are generated by vehicles as well as earth moving equipment, lifting equipment, cutting and bombing equipment, various sirens and sirens. In the borrowing area, noise and dust are generated by vehicles, earth moving equipment, various sirens, sirens and the occasional detonation of explosives.

Roads, paths, and transportation lines intersect across land areas. In this type of habitat a number of mammals may be found, including sand fox, porcupine, rattlesnake, civet, porpoise, hedgehog, and wild cat. None of these mammals are endangered or of particular environmental importance. In the construction site of the dam and borrowing areas in riverine habitats, the wildlife is mainly composed of birds but there may be a pig, green monkey, crocodile and snake (Schexnayder and Ernzen1999; Ouren et al., 2007).

\subsubsection{Impacts during Reservoir Filling}

\subsubsection{Out-Migration}

The inundation event have a number of complex impacts on the terrestrial fauna, which react in a number of ways, mainly out-migration and drowning. There is a timber and/or biomass clearance this could disturb many of the larger animals and cause them to leave the area. Even if these activities do not occur most large animals, and highly mobile small animals, will successfully leave the area as the water rises. It must be appreciated that the inundation event runs steadily through a 24-hour period, offering strictly nocturnal and strictly diurnal animals special problems. Sometimes the displaced animals may survive drowning, but usually they cannot be displaced and this causes a very rapid death rate. Even those animals which successfully establish themselves after displacement will temporarily at least, until population pressures decline through natural regulation processes, be subject with all other members of the species and its competitors, to higher rates of mortality (Barraclough and Ghimire,1995).

The ecological instability generated by the flooding of a large area and the consequent movement of large numbers of animals can have an impact on public health and on crop pests. If large numbers of rodents and carnivore are displaced the human health environment be disturbed. For similar reasons crop pests if became a more serious problem for period on fields close to the reservoir. This situation will require monitoring during, and immediately after, reservoir filling (Riley et al., 2010).

\subsubsection{Drowning Of Animals}

Most of the more rapidly moving fauna have may be leave the inundation area during clearing of trees and biomass destruction (if these measures are taken).

Those which remain in the area or which return became trapped on the numerous temporary islands which form as inundation proceeds (due to the depth of the reservoir and the local topography), because it is not anticipated that permanent islands be created, animals trapped on islands will eventually drown unless they can swim to the shore. (Maltby, 2013).

Most of the animals that drown will be small flightless terrestrial mammals, immature and injured animals incapable of moving, and soil fauna. The bodies of drowned animals represent contribution to the total biomass decomposition.

\subsubsection{Impacts during Operation}

\subsubsection{Reservoir Area}

The impact on the wildlife is associated with the physical presence of the reservoir, which is a source of water available all year round, whereas for the baseline situation, the rivers are almost dry for several months of the year. The increased availability of water should be beneficial for some of the wildlife; however other factors need to be taken into consideration. The flooding of the reservoir; which destroy the Riverine habitat, cause the wildlife from these areas (sand fox, porcupine, ratel, civet, aardvark, hedgehog, wild cat, warthog) (Bartram and Ballance, 1996).

\subsubsection{Mitigation}

It is necessary to consider the prevailing attitudes of the developed world with respect to animals living in distant locations perceived as natural and unspoiled. It must be some measures, limited to the actual periods of rapid inundation, should be taken to provide safe retreats for the slow moving flood survivors.

For some dam projects, must be boat patrols are made during filling to capture stranded specimens and provide safe retreat and collection of slow moving survivors using tethered floating rafts.

The fleeing of the animals be the opportunity for the local population to hunt the fleeing animals and therefore the most effective means of protecting the fleeing animals will be to implement an effective means enforcing a ban on hunting. 


\subsection{Impacts on Air Quality}

\subsubsection{Dust and Air Emissions from Construction Activities}

Most of the air pollution will originate from the fugitive dust resulting from traffic on the road and the earthworks and from the release of smoke from trucks and heavy equipment engines. Water spraying must be the primary protection measure against dust. Stabilization of spoil areas by herbaceous vegetation must be reduce the risk of fugitive dust during windy days during the dry season. Smoke emissions from engines can also be controlled by appropriate maintenance of engines. Additional sources of smoke result from clearing and burning of vegetation at the construction sites, at the early stages of the construction phase, and from burning of waste and refuse (Faber et al., 2015).

\subsubsection{Impacts on Climate}

2.6.2.1. Greenhouse Gas Emissions and Contribution to Global Warming

Greenhouse gases, namely carbon dioxide and methane into the atmosphere, are released from reservoirs that flood forests and biomass sometimes slowly if the submerged organic matter decomposes or rapidly if forests are cut down and disposed of by burning before the reservoir is filled. It has been recognized that dam reservoirs throughout the world emit Greenhouse Gases (GHG) that contribute to global warming. The GHG emissions from different dams vary greatly because the emissions are dependent on many factors. Greenhouse gases emitted from dam reservoirs comprises methane (CH4). The Global Warming Potential (GWP) of methane is 25 , i.e. one kilogram me of methane is equivalent to 25 kilograms of carbon dioxide.

\subsubsection{Impacts on Micro-Climate}

The impounding of the reservoir create a large water body that may influence the local climate. The annual water loss from the reservoir from evaporation is estimated using the average annual local value of Potential Evapotranspiration (PET). Because of the evaporation of water and the cooling effect of storing the water, the climate in the immediate vicinity of the reservoir is to have increase in humidity and temperature (Marsalek et al., 2008).

\subsubsection{Mitigation}

The dust emissions from trucks transporting rock material using unpaved tracks should be minimized. The principal concern is with respect to dust emissions close to regions. However the other villages will be exposed to dust emissions. Means of controlling dust can be performed by regular water spraying to suppress the dust and/or to pave sections of the track. Because water spraying represents a number of organizational difficulties, the most suitable solution will be to pave the sections of tracks that are close to regions. With respect to climate and GHG emissions, the mitigation measure is to clear vegetation prior to reservoir filling. This mitigation is also applicable to problems of water quality.

\section{TABLES}

Table.1: Summary of Impacts - Physical Environment (Ledec and Quintero, 2003; Wahlstrom, 2012 and Baxter, 1977).

\begin{tabular}{|c|c|c|c|}
\hline Activity & Dam sites and construction sites & Reservoir area & Downstream areas \\
\hline \multicolumn{4}{|c|}{ Sediment, soils, land cover, seismicity } \\
\hline \multirow{3}{*}{ Construction } & $\begin{array}{l}\text { Physical disturbance of top soils at } \\
\text { construction site }\end{array}$ & \multirow{3}{*}{$\begin{array}{l}\text { Extraction of sand } \\
\text { and gravel for dam } \\
\text { construction. }\end{array}$} & \multirow{3}{*}{$\begin{array}{l}\text { Dumping of extracted soils } \\
\text { and rock from the dam } \\
\text { construction. }\end{array}$} \\
\hline & $\begin{array}{l}\text { Physical disturbance from access road } \\
\text { construction and transmission line right } \\
\text { of way }\end{array}$ & & \\
\hline & $\begin{array}{l}\text { Potential for unauthorized dumping of } \\
\text { hazardous waste. Similar level of risk } \\
\text { for the three options }\end{array}$ & & \\
\hline $\begin{array}{l}\text { Reservoir } \\
\text { filling }\end{array}$ & $\begin{array}{l}\text { Low risk of reservoir induced } \\
\text { earthquake. }\end{array}$ & Change in land use & No predicted impacts \\
\hline $\begin{array}{l}\text { Reservoir } \\
\text { operation }\end{array}$ & $\begin{array}{l}\text { The impacts incurred during } \\
\text { construction and filling. }\end{array}$ & Sediment deposition & $\begin{array}{l}\text { Modification of river } \\
\text { morphology, erosion of banks, } \\
\text { deposition of sediment. }\end{array}$ \\
\hline
\end{tabular}

Table (1) Continue 


\begin{tabular}{|c|c|c|c|}
\hline Activity & Dam sites and construction sites & Reservoir area & Downstream areas \\
\hline \multicolumn{4}{|c|}{ Groundwater } \\
\hline Construction & \multicolumn{3}{|c|}{$\begin{array}{l}\text { Potential for contamination from unauthorised dumping of hazardous waste and leaks and spills } \\
\text { from fuel and chemical storage and handling. This risk is approximately the same for all three } \\
\text { options }\end{array}$} \\
\hline $\begin{array}{l}\text { Reservoir } \\
\text { filling }\end{array}$ & $\begin{array}{l}\text { Potential for resurgences of } \\
\text { groundwater causing water logging is } \\
\text { some area. }\end{array}$ & \multirow[b]{2}{*}{$\begin{array}{l}\text { Seepage of reservoir } \\
\text { water into } \\
\text { underlying aquifer. }\end{array}$} & $\begin{array}{l}\text { Potential for resurgences of } \\
\text { groundwater causing water } \\
\text { logging in some area. }\end{array}$ \\
\hline $\begin{array}{l}\text { Reservoir } \\
\text { operation }\end{array}$ & $\begin{array}{l}\text { The impacts incurred during } \\
\text { construction and filling are predicted }\end{array}$ & & $\begin{array}{l}\text { Groundwater may be } \\
\text { contaminated occasionally } \\
\text { with anoxic or eutrophic water } \\
\text { from seepage of reservoir } \\
\text { water. Will occur when anoxic } \\
\text { or eutrophic conditions occur } \\
\text { in the reservoir. }\end{array}$ \\
\hline \multicolumn{4}{|c|}{ Air } \\
\hline Construction & $\begin{array}{l}\text { Emissions of dust, construction vehicle } \\
\text { exhaust fumes and work camp power } \\
\text { generation emissions. }\end{array}$ & $\begin{array}{l}\text { No predicted } \\
\text { significant } \\
\text { impacts }\end{array}$ & $\begin{array}{l}\text { Possible impacts from } \\
\text { dispersion of dust from } \\
\text { blasting }\end{array}$ \\
\hline $\begin{array}{l}\text { Reservoir } \\
\text { filling }\end{array}$ & No predicted significant impacts & $\begin{array}{l}\text { No predicted } \\
\text { significant } \\
\text { impacts }\end{array}$ & $\begin{array}{l}\text { No predicted significant } \\
\text { impacts }\end{array}$ \\
\hline \multirow{3}{*}{$\begin{array}{l}\text { Reservoir } \\
\text { operation }\end{array}$} & \multicolumn{3}{|c|}{ Greenhouse gas emissions from biodegradation of inundated vegetation } \\
\hline & \multicolumn{3}{|c|}{ Greenhouse gas emissions from occasional anoxic conditions. } \\
\hline & \multicolumn{3}{|c|}{$\begin{array}{l}\text { Creation of microclimate. The evaporation of water from the reservoir may cause a } \\
\text { noticeable increase in the local climate. }\end{array}$} \\
\hline
\end{tabular}

\begin{tabular}{|c|c|c|c|}
\hline \multicolumn{4}{|c|}{ Hydrology } \\
\hline $\begin{array}{l}\text { Constructio } \\
\mathrm{n}\end{array}$ & $\begin{array}{l}\text { Potential for contamination from } \\
\text { unauthorised dumping of hazardous } \\
\text { waste and leaks and spills from fuel } \\
\text { and chemical storage and handling. }\end{array}$ & $\begin{array}{l}\text { Potential for } \\
\text { contamination from } \\
\text { unauthorised dumping } \\
\text { of hazardous waste. }\end{array}$ & $\begin{array}{l}\text { Potential for contamination from } \\
\text { unauthorised dumping of } \\
\text { hazardous waste. } \\
\text { Possible impacts from } \\
\text { construction camp wastewater }\end{array}$ \\
\hline $\begin{array}{l}\text { Reservoir } \\
\text { filling }\end{array}$ & \multicolumn{2}{|c|}{$\begin{array}{l}\text { Floating debris, rubbish from inundated villages and trees, } \\
\text { branches and vegetation from inundated area. }\end{array}$} & $\begin{array}{l}\text { Reduced flow of water and } \\
\text { consequently reduced availability } \\
\text { of drinking water for people cattle } \\
\text { and reduced water for irrigated } \\
\text { lands on the banks of the river. }\end{array}$ \\
\hline \multirow{2}{*}{$\begin{array}{l}\text { Reservoir } \\
\text { operation }\end{array}$} & $\begin{array}{l}\text { Eutrophic and/or anoxic conditions } \\
\text { inundated vegetation }\end{array}$ & rom biodegradation of & \multirow{2}{*}{$\begin{array}{l}\text { The water quality will be } \\
\text { occasionally degraded when } \\
\text { eutrophic and/or anoxic conditions } \\
\text { occur in the reservoir }\end{array}$} \\
\hline & $\begin{array}{l}\text { Occasional anoxic or eutrophic con } \\
\text { reservoir }\end{array}$ & itions occur in the & \\
\hline \multicolumn{4}{|c|}{ Noise } \\
\hline $\begin{array}{l}\text { Constructio } \\
\mathrm{n}\end{array}$ & $\begin{array}{l}\text { Noise from construction work } \\
\text { and traffic }\end{array}$ & $\begin{array}{l}\text { Noise from vehicles of } \\
\text { land clearing teams and } \\
\text { dredging of } \\
\text { construction material } \\
\text { (sand and gravel) }\end{array}$ & $\begin{array}{l}\text { Noise from dredging of } \\
\text { construction material (sand and } \\
\text { gravel) }\end{array}$ \\
\hline
\end{tabular}




\begin{tabular}{|c|l|l|l|}
\hline $\begin{array}{l}\text { Reservoir } \\
\text { filling }\end{array}$ & $\begin{array}{l}\text { No predicted significant } \\
\text { impacts }\end{array}$ & $\begin{array}{l}\text { No predicted } \\
\text { significant impacts }\end{array}$ & $\begin{array}{l}\text { No predicted significant } \\
\text { impacts }\end{array}$ \\
\hline $\begin{array}{l}\text { Reservoir } \\
\text { operation }\end{array}$ & Noise from turbines & $\begin{array}{l}\text { No significant } \\
\text { impacts predicted }\end{array}$ & $\begin{array}{l}\text { No significant impacts } \\
\text { predicted }\end{array}$ \\
\hline
\end{tabular}

Table.2: Summary of Impacts - Biological Environment (Ledec and Quintero, 2003; Wahlstrom, 2012 and Baxter, 1977).

\begin{tabular}{|c|c|c|c|}
\hline Activity & Dam sites and construction sites & Reservoir area & Downstream areas \\
\hline \multicolumn{4}{|c|}{ Aquatic ecology } \\
\hline Construction & $\begin{array}{l}\text { Loss of habitat for fish and aquatic } \\
\text { life. }\end{array}$ & $\begin{array}{l}\text { Physical disturbance } \\
\text { of fish and aquatic life } \\
\text { from the extraction of } \\
\text { sand and gravel from } \\
\text { the borrow areas some } \\
\text { of which are located in } \\
\text { the river bed. }\end{array}$ & $\begin{array}{l}\text { Construction work may incur } \\
\text { release of sediment in the river } \\
\text { downstream of the dam } \\
\text { construction site. The impact is } \\
\text { expected to be of no } \\
\text { significance }\end{array}$ \\
\hline $\begin{array}{r}\text { Reservoir } \\
\text { filling }\end{array}$ & \multirow{2}{*}{\multicolumn{2}{|c|}{$\begin{array}{l}\text { Increased fish population numbers in the new reservoir, } \\
\text { however there will be a change in biodiversity }\end{array}$}} & \multirow{3}{*}{$\begin{array}{l}\text { The dam may present a } \\
\text { physical barrier for migration } \\
\text { of fish }\end{array}$} \\
\hline & & & \\
\hline Reservoir operation & \multicolumn{2}{|c|}{$\begin{array}{l}\text { Risk of development of aquatic weeds and/or conditions favourable } \\
\text { for disease vectors such as mosquitoes and vector snails of } \\
\text { schistosomiasis }\end{array}$} & \\
\hline \multicolumn{4}{|c|}{ Terrestrial vegetation } \\
\hline Construction & $\begin{array}{l}\text { Loss of natural vegetation at dam site } \\
\text { and along access road and transmission } \\
\text { line right of way }\end{array}$ & $\begin{array}{l}\text { No significant } \\
\text { impacts predicted }\end{array}$ & $\begin{array}{l}\text { No significant impacts } \\
\text { predicted }\end{array}$ \\
\hline $\begin{array}{l}\text { Reservoir } \\
\text { filling }\end{array}$ & \multicolumn{2}{|l|}{ Loss of natural vegetation } & $\begin{array}{l}\text { No significant impacts } \\
\text { predicted }\end{array}$ \\
\hline Reservoir operation & \multicolumn{2}{|c|}{$\begin{array}{l}\text { No further negative impact compared to that of construction and } \\
\text { reservoir filling. However the reservoir may represent a } \\
\text { favourable habitat for introduction of new species }\end{array}$} & $\begin{array}{l}\text { Reduced water for riparian } \\
\text { vegetation, reduced numbers } \\
\text { and biodiversity }\end{array}$ \\
\hline \multicolumn{4}{|c|}{ Wildlife } \\
\hline \multirow{2}{*}{ Construction } & $\begin{array}{l}\text { Loss of habitat will affect wildlife } \\
\text { causing them to flee the area }\end{array}$ & $\begin{array}{l}\text { No significant } \\
\text { impacts predicted }\end{array}$ & $\begin{array}{l}\text { No significant impacts } \\
\text { predicted }\end{array}$ \\
\hline & \multicolumn{3}{|c|}{$\begin{array}{l}\text { Possible hunting of wildlife by construction site workers. The crocodile (protected species) and } \\
\text { or gazelle and antelope may be at risk from hunting }\end{array}$} \\
\hline $\begin{array}{l}\text { Reservoir } \\
\text { filling }\end{array}$ & \multicolumn{2}{|c|}{$\begin{array}{l}\text { Animals will be forced to flee the area and some animals will be } \\
\text { drowned or stranded on islands }\end{array}$} & $\begin{array}{l}\text { Influx of animals from the } \\
\text { inundated area into the } \\
\text { downstream areas }\end{array}$ \\
\hline Reservoir operation & \multicolumn{2}{|l|}{ The area may attract birdlife to the area } & $\begin{array}{l}\text { No significant impacts } \\
\text { predicted }\end{array}$ \\
\hline
\end{tabular}

\section{CONCLUSION}

It concluded that, the most important impacts of dams are the effects on water and air quality, because they are the basic elements which affect directly on humans, animals and plants. The effectiveness on water quality due to excessive sediment release, pollution from hazardous 
materials; household wastewater and solid waste. While the most dangerous impacts on air quality is the emission of greenhouse gases (carbon dioxide, methane).

\section{REFERENCES}

[1] Ashton, P. J., Love, D., Mahachi, H. \& Dirks, P. H. G. M. (2001). An overview of the impact of mining and mineral processing operations on water resources and water quality in the Zambezi, Limpopo and Olifants Catchments in Southern Africa. Contract Report to the Mining, Minerals and Sustainable Development (Southern Africa) Project, by CSIR-Environmentek, Pretoria and Geology Department, University of Zimbabwe-Harare. Report No. ENV-PC, 42, 1362 .

[2] Assessment, M. E. (2005). Ecosystems and human wellbeing. Vol. 5. United States of America: Island press.

[3] Bai, J., Xiao, R., Cui, B., Zhang, K., Wang, Q., Liu, X. \& Huang, L. (2011). Assessment of heavy metal pollution in wetland soils from the young and old reclaimed regions in the Pearl River Estuary, South China. Environmental pollution, 159(3), 817-824.

[4] Barraclough, S. \& Ghimire, K. (1995). Forests and livelihoods: the social dynamics of deforestation in developing countries. Springer.

[5] Bartram, J. \& Ballance, R. (Eds.). (1996). Water quality monitoring: a practical guide to the design and implementation of freshwater quality studies and monitoring programmes. CRC Press.

[6] Basson, G. (2004). Hydropower dams and fluvial morphological impacts-an African perspective. In Paper from United Nations Symposium on Hydropower and Sustainable Development (pp. 27-29).

[7] Baxter, R. M. (1977). Environmental effects of dams and impoundments. Annual review of ecology and systematics, 255-283.

[8] Beilfuss, R. D., Dutton, P. \& Moore, D. (2000). Land cover and land use change in the Zambezi delta. Biodiversity of the Zambezi basin wetlands, 3, 31-106.

[9] Carpenter, S. R., Cole, J. J., Essington, T. E., Hodgson, J. R., Houser, J. N., Kitchell, J. F. \&Pace, M. L. (1998). Evaluating alternative explanations in ecosystem experiments. Ecosystems, 1(4), 335-344.

[10] Chandrappa, R. \& Das, D. B. (2012). Solid waste management: Principles and practice. Springer Science \& Business Media.

[11] Coutant, C. C. (1999). Perspectives on temperature in the Pacific Northwest's fresh waters (No. ORNL/TM-1999/44). Oak Ridge National Lab., TN (US).

[12] Ellison, D. H. (2007). Handbook of chemical and biological warfare agents. CRC press.

[13] Erikson, K. (1976). Everything in its path. Simon and Schuster.

[14] Faber, P., Drewnick, F. \& Borrmann, S. (2015). Aerosol particle and trace gas emissions from earthworks, road construction, and asphalt paving in Germany: Emission factors and influence on local air quality. Atmospheric Environment, 122, 662-671.
[15] Furey, P. C., Nordin, R. N. \& Mazumder, A. (2004). Water level drawdown affects physical and biogeochemical properties of littoral sediments of a reservoir and a natural lake. Lake and Reservoir Management, 20(4), 280-295.

[16] Gadgil, M. \& Guha, R. (1994). Ecological conflicts and the environmental movement in India. Development and change, 25(1), 101-136.

[17] Goldman, C. R. (1976). Ecological aspects of water impoundment in the tropics. Revista de biologia tropical, 87112.

[18] Gruner, E. (1963). Dam disasters. Proceedings of the institution of civil engineers, 24(1), 47-60.

[19] Huesemann, M. \& Huesemann, J. (2011). Techno-fix: why technology won't save us or the environment. New Society Publishers.

[20] Jafarinejad, S. (2016). Petroleum waste treatment and pollution control. Butterworth-Heinemann.

[21] Jean-Baptiste, P., Baumier, D., Fourre, E., Dapoigny, A., \& Clavel, B. (2007). The distribution of tritium in the terrestrial and aquatic environments of the Creys-Malville nuclear power plant (2002-2005). Journal of environmental radioactivity, 94(2), 107-118.

[22] Kondolf, G. M., Piégay, H. \& Landon, N. (2007). Changes in the riparian zone of the lower Eygues River, France, since 1830. Landscape Ecology, 22(3), 367-384.

[23] Kumari, D. \& Singh, R. (2018). Pretreatment of lignocellulosic wastes for biofuel production: a critical review. Renewable and Sustainable Energy Reviews, 90, 877891.

[24] Kunz, M. J., Wüest, A., Wehrli, B., Landert, J. \& Senn, D. B. (2011). Impact of a large tropical reservoir on riverine transport of sediment, carbon, and nutrients to downstream wetlands. Water Resources Research, 47(12).

[25] la Cecilia, D., Toffolon, M., Woodcock, C. E. \& Fagherazzi, S. (2016). Interactions between river stage and wetland vegetation detected with a Seasonality Index derived from LANDSAT images in the Apalachicola delta, Florida. Advances in Water Resources, 89, 10-23.

[26] Ledec, G. \& Quintero, J. D. (2003). Good dams and bad dams: environmental criteria for site selection of hydroelectric projects. Publisher, City, Country?

[27] Lewis, B. (2002). Farm dams: planning, construction and maintenance. Landlinks Press.

[28] Loucks, D. P., \& Van Beek, E. (2017). Water resource systems planning and management: An introduction to methods, models, and applications. Springer.

[29] Maltby, E. (2013). Waterlogged wealth: why waste the world's wet places?. Routledge.

[30] Marsalek, J., Cisneros, B. J., Karamouz, M., Malmquist, P. A., Goldenfum, J. A. \& Chocat, B. (2008). Urban water cycle processes and interactions: Urban Water Series-UNESCOIHP (Vol. 2). CRC Press.

[31] McCully, P. (1996). Silenced rivers: The ecology and politics of large dams. Zed Books.

[32] Miller, J. R. \& Miller, S. M. O. (2007). Contaminated rivers: a geomorphological-geochemical approach to site assessment and remediation. Springer Science \& Business Media. 
[33] Miranda, L. E. (2001). A review of guidance and criteria for managing reservoirs and associated riverine environments to benefit fish and fisheries. FAO fisheries technical paper, 419, 91-137.

[34] Mollema, P. N. (2016). Water and chemical budgets of gravel pit lakes: Case studies of fluvial gravel pit lakes along the Meuse River (The Netherlands) and coastal gravel pit lakes along the Adriatic Sea (Ravenna, Italy).

[35] Murakami, M. (1995). Managing water for peace in the Middle East: alternative strategies. United Nations University Press.

[36] Naja, G. M. \& Volesky, B. (2009). Toxicity and sources of $\mathrm{Pb}, \mathrm{Cd}, \mathrm{Hg}, \mathrm{Cr}, \mathrm{As}$, and radionuclides in the environment. Heavy metals in the environment, 8, 16-18.

[37] Patz, J. A., Graczyk, T. K., Geller, N. \& Vittor, A. Y. (2000). Effects of environmental change on emerging parasitic diseases. International journal for parasitology, 30(12-13), 1395-1405.

[38] Power, M. E., Dietrich, W. E. \& Finlay, J. C. (1996). Dams and downstream aquatic biodiversity: potential food web consequences of hydrologic and geomorphic change. Environmental management, 20(6), 887-895.

[39] Ouren, D. S., Haas, C., Melcher, C. P., Stewart, S. C., Ponds, P. D., Sexton, N. R., \& Bowen, Z. H. (2007). Environmental effects of off-highway vehicles on Bureau of Land Management lands: A literature synthesis, annotated bibliographies, extensive bibliographies, and internet resources. US Geological Survey, Open-File Report, 1353, 225.

[40] Richter, B. D., Postel, S., Revenga, C., Scudder, T., Lehner, B., Churchill, A., \& Chow, M. (2010). Lost in development's shadow: the downstream human consequences of dams. Water Alternatives, 3(2), 14-42.

[41] Riley, S. P., Cypher, B. L. \& Gehrt, S. D. (2010). Urban carnivores. JHU Press.

[42] Robles, J. D. (2010). The FDI and regional development in Chile (Doctoral dissertation, University of Illinois at UrbanaChampaign).

[43] Roht-Arriaza, N. (2009). First, do no harm: human rights and efforts to combat climate change. Georgia Journal of International and Comparative Law, 38, 593.

[44] Schexnayder, C. J. \& Ernzen.j (1999). Mitigation of nighttime construction noise, vibrations, and other nuisances , Synthesis of highway practice (No. 218). Transportation Research Board,National Academy Paress Washington.

[45] Skaggs, R. W., Breve, M. A. \& Gilliam, J. W. (1994). Hydrologic and water quality impacts of agricultural drainage Critical reviews in environmental science and technology, 24(1), 1-32.

[46] Spoor, W. A. (1990). Distribution of fingerling brook trout, Salvelinus fontinalis (Mitchill), in dissolved oxygen concentration gradients. Journal of Fish Biology, 36(3), $363-$ 373.

[47] Stevens, M. A. (2000). Reservoir sedimentation handbookdesign and management of dams, reservoirs, and watershed for sustainable use. Journal of Hydraulic Engineering, 126(6), 481-482.
[48] Tatsi, A. A. \& Zouboulis, A. I. (2002). A field investigation of the quantity and quality of leachate from a municipal solid waste landfill in a Mediterranean climate (Thessaloniki, Greece). Advances in Environmental Research, 6(3), 207219.

[49] Tealdi, S., Camporeale, C. \& Ridolfi, L. (2011). Modeling the impact of river damming on riparian vegetation. Journal of hydrology, 396(3-4), 302-312.

[50] Tibaijuka, A. k. (2009). Building prosperity: Housing and economic development. Earthscan, London, UK.

[51] Visser, F., Wasson, R. J. \& Prosser, I. (2002). Quantifying sediment sources in lowlying sugarcane land. The Structure, Function and Management Implications of Fluvial Sedimentary Systems, (276), 169.

[52] Wahlstrom, E. (2012). Dams, dam foundations, and reservoir sites (Vol. 6). Elsevier.

[53] Ward, J. V., Bretschko, G., Brunke, M., Danielopol, D., Gibert, J., Gonser, T. \& Hildrew, A. G. (1998). The boundaries of river systems: the metazoan perspective. Freshwater Biology, 40(3), 531-569.

[54] Webb, B. W., Foster, I. D. L. \& Gurnell, A. M. (1995). Hydrology, water quality and sediment behaviour (pp. 1-30). John Wiley and Sons Ltd., Chichester.

[55] Wetzel, R. G. (2001). Limnology: lake and river ecosystems. Gulf professional publishing.

[56] Zimmer, M. (2008). Detritus. General ecology, 2, 903-911. 